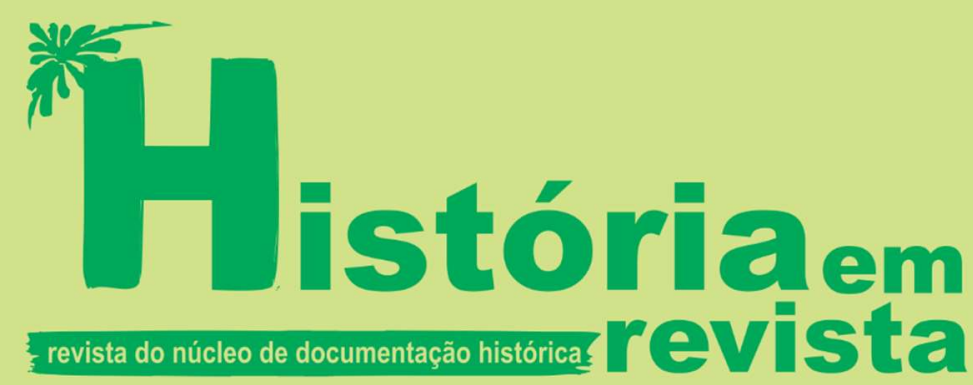

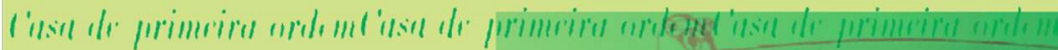

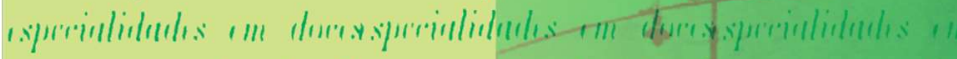

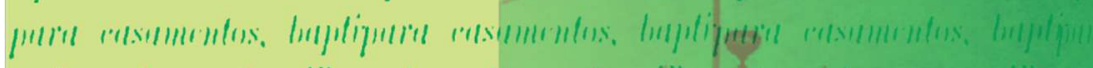

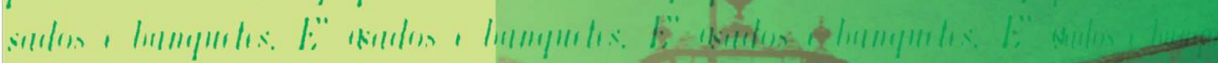

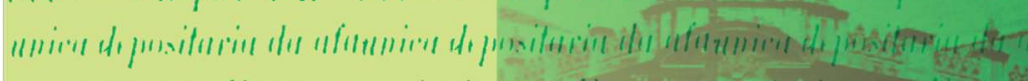

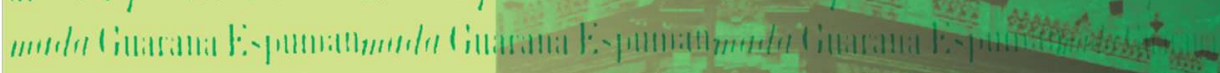

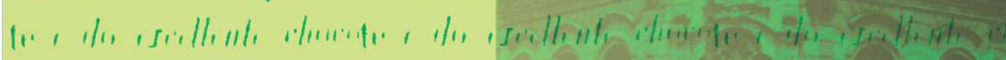

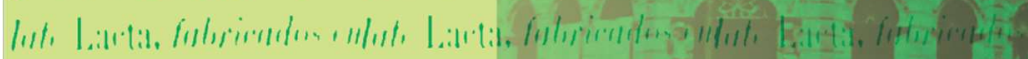

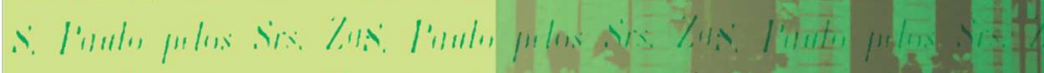

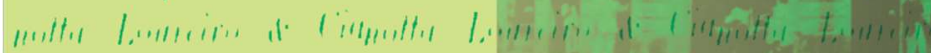

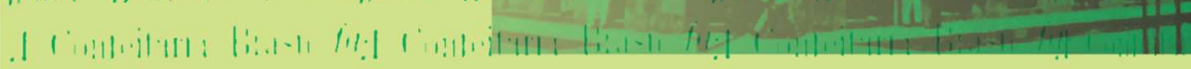




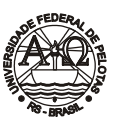

Obra publicada pela Universidade Federal de Pelotas Reitor: Pedro Rodrigues Curi Hallal Vice-Reitor: Luis Isaías Centeno do Amaral

Chefe de Gabinete: Aline Elias Lamas

Pró-Reitor de Graduação: Maria de Fátima Cóssio

Pró-Reitor de Pesquisa e Pós-Graduação: Flávio Fernando Demarco

Pró-Reitor de Extensão e Cultura: Francisca Ferreira Michelon

Pró-Reitor de Planejamento e Desenvolvimento: Otávio Martins Peres

Pró-Reitor Administrativo: Ricardo Hartlebem Peter

Pró-Reitor de Infra-estrutura: Julio Carlos Balzano de Mattos

Pró-Reitor de Assuntos Estudantis: Mário Renato de Azevedo Jr.

Pró-Reitor de Gestão Pessoas: Sérgio Batista Christino

\section{CONSELHO EDITORLAL}

Representante das Ciências Agronômicas: Guilherme Albuquerque de Oliveira Cavalcanti (Titular), Cesar Valmor Rombaldi (suplente) e Fabrício de Vargas Arigony Braga (suplente) | Representantes da Área das Ciências Exatas e da Terra: Adelir José Strieder (titular) e Juliana Pertille da Silva (suplente) | Representante da Área das Ciências Biológicas: Raquel Ludke (suplente) | Representante da Área das Engenharias e Computação: Darci Alberto Gatto | Representantes da Área das Ciências da Saúde: Claiton Leoneti Lencina (titular) e Giovanni Felipe Ernst Frizzo (suplente) | Representante da Área das Ciências Sociais Aplicadas: Célia Helena Castro Gonsales | Representante da Área das Ciências Humanas: Charles Pereira Pennaforte e Guilherme Camargo Massaú (suplente) | Representantes da Área das Linguagens e Artes: Josias Pereira da Silva (titular) e Maristani Polidori Zamperetti (suplente)

\section{INSTITUTO DE CIÊNCLAS HUMANAS}

Diretor: Prof. Dr. Sidney Gonçalves Vieira

Vice-Diretor: Prof. Dr. Sebastião Peres

\section{NÚCLEO DE DOCUMENTACÃO HISTÓRICA}

Coordenadora:

Prof ${ }^{a}$ Dra. Lorena Almeida Gill

Membros do NDH:

Prof ${ }^{a}$ Dra. Beatriz Ana Loner

Prof ${ }^{a}$ Dra. Lorena Almeida Gill

Prof. Dr. Paulo Ricardo Pezat

Prof. Dr. Aristeu Elisandro Machado Lopes

Técnico Administrativo:

Paulo Luiz Crizel Koschier

HISTÓRIA EM REVISTA - Publicação do Núcleo de Documentação Histórica

Comissão Editorial:

Prof. Dr. Aristeu Elisandro Machado Lopes

Prof ${ }^{a}$ Dra. Beatriz Ana Loner

Prof ${ }^{a}$ Dra. Lorena Almeida Gill

Prof. Dr. Paulo Ricardo Pezat

Conselho Editorial:

Prof ${ }^{a}$ Dra. Helga I. Landgraf Piccolo (UFRGS)

Prof. Dr. René Gertz (UFRGS) (PUCRS)

Prof. Ms. Mario Osorio Magalhães (UFPel)

Prof. Dr. Temístocles A. C. Cezar (UFRGS)

Profa. Dra. Beatriz Teixeira Weber (UFSM)

Prof ${ }^{a}$. Dra. Maria Cecília V. e Cruz (UFBA)

Prof. Dr. Marcelo Badaró Mattos (UFF)

Profa. Dra. Joan Bak (Univ. Richmond - USA)

Prof. PhD Pablo Alejandro Pozzi (Universidad de Buenos Aires).

Prof. Tommaso Detti (Università Degli Studi di Siena)

Editor: Prof. Dr. Aristeu Elisandro Machado Lopes

Editoração e Capa: Paulo Luiz Crizel Koschier

Editora e Gráfica Universitária

R Lobo da Costa, 447 - Pelotas, RS - CEP 96010-150 |

Fone/fax: (53) 32278411

e-mail: editora@ufpel.edu.br

\section{Impresso no Brasil}

Edicão: 2017

ISSN - 1516-2095

Dados de catalogação na fonte: Aydê Andrade de Oliveira - CRB - 10/864

História em revista / publicação do Núcleo de Documentação Histórica. Instituto de Ciências Humanas. Universidade Federal de Pelotas. v.23, (dez. 2017). - Pelotas: Editora da UFPel, 2017.

$1 \mathrm{v}$.

Anual

ISSN 1516-2095

1. História - Periódicos. I. Núcleo de Documentação Histórica. Instituto de Ciências Humanas. Universidade Federal de Pelotas. CDD 930.005

\section{Indexada pela base de dados Worldcat Online Computer Library Center}

\section{PEDE-SE PERMUTA} WE ASK FOR EXCHANGE

UFPel/NDH/Instituto de Ciências Humanas

Rua Cel. Alberto Rosa, 154

Pelotas/RS - CEP: 96010-770

Caixa Postal 354

Fone: (53) 32843208

\section{http://wp.ufpel.edu.br/ndh/} e-mail:ndh.ufpel@gmail.com 


\title{
JEAN ROCHE NAS ENTRELINHAS DE JOSUÉ GUIMARÃES: A INFLUÊNCIA DE A COLONIZAÇÃO ALEMÃ E O RIO GRANDE DO SUL NA CONSTRUÇÃO DE $A$ FERRO E FOGO
}

\author{
JEAN ROCHE IN THE SUBTEXTO OF JOSUÉ GUIMARÃES: THE INFLUENCE OF A \\ COLONIZAÇÃO ALEMÃ E O RIO GRANDE DO SUL IN THE CONSTRUCTION OF A \\ FERRO E FOGO
}

Eduardo Ortiz ${ }^{1}$

\begin{abstract}
Resumo: O presente trabalho tem como objetivo investigar as relações entre história e literatura a partir dos romances históricos A ferro e fogo: tempo de solidão e A ferro e fogo: tempo de guerra, de Josué Guimarães, juntamente aos dois tomos da obra A colonização alemã e o Rio Grande do Sul, do historiador francês Jean Roche, analisando a forma como a narrativa do historiador serve de fonte de pesquisa para o romancista e o processo de ficcionalização da história.
\end{abstract}

Palavras-chave: A ferro e fogo; Josué Guimarães; Jean Roche; história; literatura

\section{Introdução}

História e literatura, por mais laceradas que estejam de aporias relacionadas a contraposição entre as variações imaginativa apresentadas pela ficção e a reinscrição proposta pela história, possuem percursos e efeitos muito próximos, pelo menos no que diz respeito às representações temporais e à produção de discursos sobre o passado. Ambas buscam responder "às indagações dos homens sobre o mundo, em todas as épocas." (PESAVENTO, 2003, p. 32).

Tanto a história quanto a literatura constroem um mundo passado por meio de um sistema de representações coletivas organizadas em forma de texto literário. Alimentam-se de material discursivo e são mediadas pela organização subjetiva da história feita por cada escritor, colaborando para a construção de novos discursos, os quais criam memórias, e por meio delas, também esquecimentos.

Dessa maneira, presentificam o passado por intermédio da configuração de um determinado período e estabelecem a ordem coletiva, seguindo interesses sociais, culturais econômicos e políticos, já que ambas as

1 Graduado em Licenciatura Plena em História pela Universidade de Caxias do Sul. Mestre em Letras, Cultura e Regionalidade pela mesma instituição. E-mail: luftoriz@gmail.com 
escritas são produtos de uma determinada época e sociedade, a qual impõe influências efetivas sobre a construção e configuração da narrativa, ou ainda, como explana Certeau, no interior de uma obra não são encontrados "apenas métodos, ideias ou uma maneira de compreender, mas a sociedade a qual se refere à definição daquilo que tem sentido" (2015, p. 25).

Ambas as narrativas também produzem sobre seus leitores um efeito prático, uma vez que por intermédio da leitura, o receptor procede pelo que Ricoeur chamou de "tomar juntamente narrativo" (2010b, p. 103), por meio do qual emergem do receptor sentimentos que vão do amor e piedade, até a raiva e repulsa. Esse processo acaba por modificar as condutas do leitor, bem como a concepção que esse possui sobre o mundo, criando e reforçando valores sociais pré-estabelecidos.

Chartier, em sua obra A mão do autor e a mente do editor, atenta para questão do poder da literatura sobre a história, explicando que a "força e a energia de fábulas e ficções podem soprar vida em almas mortas" (2014, p. 8). Seguindo esse mesmo raciocínio, Chartier explica ainda que "os historiadores têm tomado consciência de que não possuem o monopólio de representar o passado e de que sua presença pode ser comunicada por relações com a história infinitamente mais poderosas que seus escritos.” (2014, p. 8).

Podemos citar como uma dessas poderosas relações com o passado o romance histórico scottiano teorizado por Georg Lukács, gênero do qual A ferro e fogo faz parte. Além de alimentar-se de material historiográfico para a sua composição, o romance histórico também utiliza das técnicas empregadas pelos historiadores, o que confere a essa narrativa a veracidade histórica dentro de sua forma ficcional.

\section{O romance histórico lukácsiano}

A teoria do romance histórico foi inicialmente publicada por Lukács em fragmentos na revista russa Literaturni Kritik, em 1936, e de forma completa em seu livro, O romance histórico, em 1937.

Georg Lukács estudava o romance histórico de maneira materialista, com base em uma visão de cunho ideológico, analisando-o enquanto "manifestação de resistência à autoridade e ao discurso monólogo do poder" (ZILBERMAN, 2003, p. 110). O autor investiga a "interação do desenvolvimento econômico e social com a visão de mundo e a forma artística que se engendram a partir desse desenvolvimento" (LUKÁCS, 2011, p. 29). Lukács prioriza em sua análise o tempo que muda de maneira abrupta, 
impactando diretamente sobre os sujeitos e suas vivências, ao invés do tempo que simplesmente passa, deixando os indivíduos inertes perante a sociedade e suas transformações.

Assim, o foco principal da narrativa são as transformações e rupturas, as quais possuem como efeito imediato a condução das massas ao "sentido histórico". Esse gênero de romance ainda "caracteriza-se por revelar forças sociais em disputa. Sua perspectiva adequada é a do cotidiano da vida prática, do flagrante de forças encarnadas em indivíduos representativos das camadas médias da população." (SANTOS, 2011, p. 283).

Outra característica dessa corrente é o estudo histórico prévio feito pelos seus seguidores, já que os romancistas históricos constantemente "revisitam o passado e dialogam com a história do país" (FERREIRA, 2009, p. 1), principalmente por meio das obras de historiadores. A partir desse embasamento documental eles podem criar seus romances, pois "a História sempre foi fonte inesgotável de inspiração para os romancistas" (FERREIRA, 2009 , p. 2).

O romance histórico scottiano, teorizado por Lukács, surgiu de uma nova tendência literária, reflexo direto dos estudos históricos pós-1848, quando historiadores e sociólogos buscavam a compreensão dos novos conflitos, dando início a uma revisão no modo de "fazer história", em que se deixa de acreditar no progresso da sociedade e passa-se a compreendê-la através da

valorização de uma substância eterna, de uma essência da natureza humana imutável, cuja organização social toma uma forma diferente em cada período da história, mas que isso não é resultado de um processo histórico ou de um progresso das ideias humanas em seu campo social. (ROMANI, 2015, p. 6).

Dessa forma, o intuito principal desse gênero literário é justamente demonstrar aos seus leitores que os destinos individuais estão conectados diretamente com o coletivo, proporcionando assim uma nova compreensão da história nacional e suas correlações com a história universal.

Em sua teoria, Lukács também enfatiza a sua percepção de arte realista, opondo-se ao que chamava de formalismo. Sua concepção de arte realista está fundamentada em uma perspectiva inteiramente histórica, ou seja, depende diretamente da história para existir, mesmo quando propõe uma tipologia de gênero romanesco, pois não deixa de lado as transformações que decorrem nas estruturas conjunturais e sociais da época representada.

Lukács também espera que no romance histórico o romancista atinja 
um deslocamento de sua época para o período que está sendo representado, a fim não apenas de evitar possíveis anacronismos, mas também de chegar a fundo à sua verdadeira natureza. $O$ teórico também deixa claro duas exigências, as quais devem ser seguidas pelos romancistas que almejam esse gênero literário.

A primeira dessas exigências é restabelecer a singularidade histórica da época representada, para que dessa maneira se possa chegar à segunda exigência, que é a "verdade histórica", a qual será obtida por meio das atuações das personagens. Esta deverá apresentar de forma explícita os costumes, hábitos, valores e as peculiaridades de uma determinada época por meio de suas atuações e de seus comportamentos, mas sem deixar de lado a naturalidade.

Foi nas obras de Walter Scott que Lukács constata inicialmente os elementos necessários para o surgimento do romance histórico. Analisando a obra Waverley, do autor escocês, publicada em 1814, Lukács vê corporificado pela primeira vez o modelo de romance histórico segundo a sua teoria, visto que nela é possível encontrar, diferentemente de todos os romances de temática histórica que a antecedera, o elemento essencialmente histórico, que é "o fato de a particularidade dos homens ativos derivar da especificidade histórica de seu tempo.” (LUKÁCS, 2011, p. 33).

O romance histórico predominou maciçamente sobre outras narrativas literárias na Europa desde a segunda década do século XIX até a primeira década do século XX. Já no Brasil, o romance histórico surge na metade do século XIX e diferencia-se de outros gêneros literários justamente por ser o projeto mais antigo e contínuo de ficção no país. Foi por meio dele que os romancistas da época acreditavam ser possível implementar, de maneira efetiva, o projeto de construção nacionalista da então jovem nação que estava se formando, por meio dos eventos que ecoavam do passado.

\section{Paul Ricoeur: tempo vivido e tempo narrado}

Paul Ricoeur, em sua obra Tempo e narrativa, traz como objeto de reflexão filosófica a relação existente entre "tempo vivido" e "tempo narrado", ou, em outras palavras, entre a "experiência" e a "consciência", abordando as relações existentes entre as estruturas narrativas empregadas pela ficção e pela história, articula a sua análise em três momentos da mímesis, denominando-as de mímesis I, mímesis II e mímesis III.

O primeiro momento da análise de Ricoeur, a mímesis I, diz respeito à 
pré-compreensão do agir humano, comum tanto ao romancista quanto ao seu leitor. É essa pré-compreensão que traça a construção da intriga por intermédio da mimética textual, e por maior força de inovação que esta possa trazer, permanecerá enraizada na experiência temporal da pré-compreensão do mundo das ações, "de suas estruturas inteligíveis, de seus recursos simbólicos e de seu caráter temporal.” (RICOEUR, 2010a, p. 96).

Bem sabemos que a intriga caracteriza-se por ser uma "imitação" da ação, mesmo assim, uma competência prévia é exigida dela, que é a capacidade de identificar a ação de maneira ampla, por meio de seus aspectos estruturais. Há também uma exigência de caráter suplementar, pois uma vez que imitar é compor uma significação que se articula com a ação, fazem-se necessárias as condições para identificar o que Ricoeur (2010a, p. 96) chamou de "mediações simbólicas da ação" (2010, p. 96), ou, em outras palavras, as articulações da ação como portadoras de atributos temporais, dos quais provem a propensão da ação de ser narrada, assim como a necessidade de narrá-la.

Já o segundo momento, a mímesis II, tem por característica configurar o processo de mediação entre a prefiguração do campo prático e a refiguração dada pela recepção da narrativa. Possui função de corte, abrindo o mundo da composição poética - do "como se" - e instituindo "a literariedade da obra literária." (RICOEUR, 2010a, p. 94), constituindo, por esse motivo, o eixo de análise da teoria de Ricoeur.

O processo de mediação da mímesis II ocorre por meio da operação de construção da intriga, a qual media os acontecimentos individuais a uma história tomada como um todo, transformando esses acontecimentos, colaboradores para o desenvolvimento da intriga, em uma história organizada de forma inteligível, possível de ser narrada e compreendida, ou ainda, nas palavras de Ricoeur, "a composição da intriga é a operação que tira de uma simples composição uma configuração." (2010a, p. 114). Dessa forma, a intriga exerce dentro de seu campo textual a função integradora e, graças a seu dinamismo, desempenha, mesmo fora de seu campo, a mediação entre "a précompreensão e [...] a pós-compreensão da ordem da ação e de seus aspectos temporais." (RICOEUR, 2010a, p.114).

O terceiro e último momento da análise de Ricoeur, a mímesis III, diz respeito a fase de encontro entre o mundo do texto literário e o mundo do leitor, ou, como explica Ricoeur, é "a intersecção entre o mundo configurado pelo poema e o mundo no qual a ação efetiva se desdobra e desdobra sua temporalidade específica" (2010a, p. 123). Nesse estágio a narrativa alcança o seu sentido pleno e é reintroduzida ao tempo do pensar e do agir, finalizando o 
percurso mimético.

Dessa forma, por intermédio da mímesis I, da mímesis II e da mímesis III, temos uma dialética entre a aporética e a poética da temporalidade, que culmina na relação entre tempo e narrativa. $\mathrm{O}$ ato de leitura é condutor da capacidade que a intriga possui de modelizar a experiência temporal, refigurando-a, marcando a entrada da obra tanto no campo da comunicação quanto no da experiência, fornecendo assim, uma temática comum tanto ao tempo da ficção, quanto ao tempo histórico, e, por mais diferenciadas que possam ser as maneiras dessas narrativas resolver suas questões com o passado, a história de maneira científica e a literatura de maneira poética, Ricoeur explica que "somos leitores de história tanto quanto de romances. Toda grafia, portanto a historiografia, remete a uma teoria aplicada da leitura." (2010c, p. 311).

Por conseguinte, é por intermédio dessa ficcionalização da história e da historicização da ficção, que tanto a história quanto a literatura concretizam as suas respectivas intencionalidades, uma "tomando de empréstimo a intencionalidade da outra.” (RICOEUR, 2010c, p. 311). E será precisamente a forma como a história se infiltra e promove rearranjos na narrativa literária, tomando de empréstimo as técnicas e a intencionalidade da narrativa científica por intermédio da obra historiográfica, que passaremos a analisar agora.

\section{O sopro de vida literário: a representação de Daniel Hillebrand}

O doutor João Daniel Hillebrand foi uma das principais lideranças históricas relacionadas à imigração alemã na Província de São Pedro do Rio Grande do Sul. Chegou à colônia de São Leopoldo em 1824, sendo um dos "dois médicos alemães [...] pagos pelo governo brasileiro" (ROCHE, 1969a, p. 97)2, a pedido do então presidente da Província, José Feliciano Fernandes Pinheiro, e do inspetor José Thomaz de Lima.

2 A partir das próximas citações de A colonização alemã e o Rio Grande do Sul indicaremos apenas o ano e a página das edições, sendo 1969a para identificar os excertos extraídos do primeiro volume e $1969 \mathrm{~b}$ do segundo. Também optamos por atualizar a ortografia das citações de acordo com as normas atuais. 


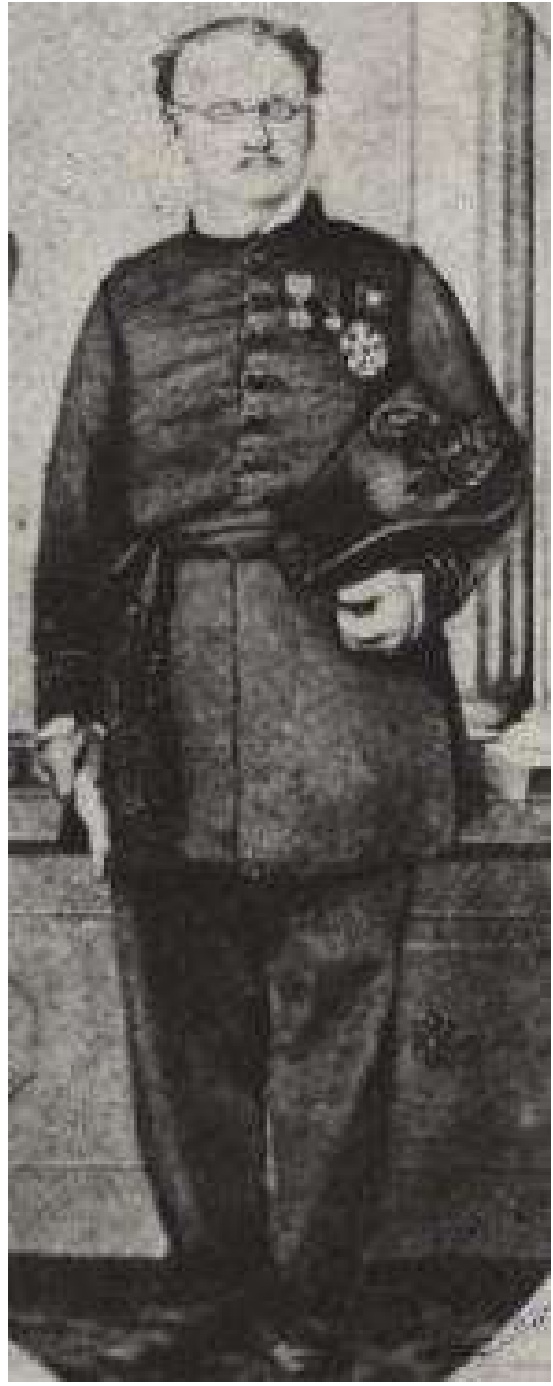

Na Colônia de São Leopoldo, João Daniel Hillebrand não foi apenas "diretor, delegado da administração central, mas também tutor e conselheiro dos colonos" (1969a, p. 104), sendo representado na obra de Josué Guimarães como "um homem sensato" (GUIMARÃES, 2008, p. 14)3. Interessante observar que a fisionomia de Hillebrand na vida real aproxima-se muito da representada no romance, como pode ser notado na Figura 1. Em A ferro e fogo, o narrador descreve a personagem com uma "fisionomia séria e tranquila" (2006, p. 65), com "os olhinhos distorcidos pelas grossas lentes" (2008, p. 5) e "míopes" (2006, p. 214).

FIGURA 1 - Dr. João Daniel Hillebrand

Fonte: Acervo Literário Josué Guimarães

A liderança de Hillebrand pode ser notada durante boa parte do romance, em que se destaca sempre que possível a sua boa relação com o recém-fundado Império Brasileiro. Podemos notar essa relação logo na primeira aparição dessa personagem, quando ela "enche-se de brios com a Guerra da Cisplatina, [...] redige um memorial endereçado ao Brigadeiro Salvador José

3 A partir das próximas citações de $A$ ferro e fogo indicaremos apenas o ano e a página das edições, sendo 2006 para identificar os excertos extraídos do primeiro volume e 2008 para os excertos do segundo. 
Maciel, colocando os alemães a serviço da causa nacional", o que vai resultar na formação da Companhia de Voluntários Alemães. A imagem dessa companhia na ficção está marcada pelo recrutamento indiscriminado de soldados alemães.

Quanto a essa prática, Roche (1969a, p. 96) explica que

o Diretor da colônia [...] preferia prevenir as perturbações a ter de reprimi-las [...] expulsou os maus sujeitos de sua colônia. [...] Quanto os mais temíveis perturbadores da ordem, aos que se chamava por eufemismo "os solteiros", reuniu-os numa "Companhia de Voluntários alemães", outro eufemismo, engajado na Segunda Guerra Cisplatina.

Para exemplificarmos essa situação, podemos observar no romance o caso de João Carlos Mayer, o qual "trouxera muitas armas contrabandeadas" (2006, p. 48) e acaba sendo pego pelas autoridades imperiais e enviado a esse batalhão.

Porém, após as humilhações passadas pelos alemães na companhia, pelo simples fato de os "voluntários" não entenderem "as ordens dadas em português" (2006, p. 48), Hillebrand fica "revoltado com o tratamento que estava sendo dado aos seus homens [e] escreve outro memorial ao presidente da Província, historiando os vexames, os sacrifícios, as chibatadas, como se fossem negros escravos." (2006, p. 49). Santos comenta sobre esses dois momentos que o Dr. Hillebrand, como "a maioria dos diretores, acende uma vela a Deus e outra ao Diabo, conforme reza o ditado popular; se, por um lado, defende os interesses dos colonos, por outro, defende os interesses do dominador." (2009, p. 49).

Nesse trecho do romance podemos perceber também o papel de liderança exercido por essa personagem, a qual entra facilmente em contato com o presidente da Província e tem o poder de questionar os modos de ação do governo em relação aos compatriotas, bem como reivindicar providências. Nesse contexto, Hillebrand tem a função de estabelecer a ligação entre os imigrantes alemães e o poder público, em geral defendendo os interesses dos primeiros - desde que isso não prejudique os seus próprios interesses.

Esse não é o único momento em que Hillebrand demonstra preocupação com os seus conterrâneos. Em outras passagens de A ferro e fogo podemos notar a inquietude dele "com o abandono a que haviam relegado aquela pobre gente. Estava disposto a viajar até Porto Alegre e, de viva voz, relatar ao presidente" (2006, p. 51). Isso acaba acontecendo em 1854, quando Hillebrand escreve um ofício em que aponta o não cumprimento por parte do governo brasileiro de cláusulas importantes do contrato firmado com 
os imigrantes antes mesmo de saírem da Alemanha. Apesar disso, destaca ele, a colônia havia progredido. O papel de liderança de Hillebrand junto aos imigrantes também se manifesta em outra situação, quando "reuniu os colonos no centro do descampado que chamavam de praça [...] cercado pelas autoridades locais, [...] fez um gesto de silêncio. Com voz grave anunciou que havia nascido na cidade do Rio de Janeiro o príncipe herdeiro D. Pedro." (2006, p. 50).

Outro momento no romance em que o Dr. Hillebrand usa de seu posto para demonstrar fidelidade, e, de certo modo, buscar prestígio pessoal perante as autoridades imperiais, ocorre quando eclode a Guerra Farroupilha.

Da mesma forma como ocorreu durante a Guerra da Cisplatina, o diretor da colônia usa de sua influência junto aos seus compatriotas para convocá-los, e por meio dessa personagem o romancista mostra o lado legalista da colônia. Essa situação pode ser notada no romance quando Catarina explica que havia "gente regimentada pelo Dr. Hillebrand [...], por sinal mais de quatrocentos compatriotas de armas na mão" (2008, p. 59), mantendo-se fiel à coroa, aguardando ordens do império para partirem à guerra. Em determinado momento, Catarina, que defendia o lado farroupilha, aconselha os amigos para que mantenham a discrição, pois havia espiões do médico "nos botecos, nos empórios e oficinas, e sempre que ficam sabendo de alguma novidade vão correndo contar a ele e aos generais do governo" (2008, p. 63), o que para ela configura uma traição.

O papel de "tutor e conselheiro dos colonos", como registra Roche (1969a, p. 104), fica claro durante boa parte de suas aparições no romance, pois, como comenta Oestereich a Catarina, "ele está sempre pronto para servir os outros, é um grande coração" (2006, p. 109). Dessa maneira, na volta de Catarina à Colônia de São Leopoldo, ela procura justamente Hillebrand para regulamentar a situação de sua família e, principalmente, de seu marido perante as autoridades do governo. Hillebrand afirma que "não há mais nada contra seu marido, ele pode trabalhar" (2006, 120), deixando dessa maneira Frau Schneider aliviada e segura para começar a sua nova vida. Nesse sentido, Hillebrand tem o poder de fazer com que as coisas de fato aconteçam na colônia, das mais complexas - que dependem de intervenção superior - às mais corriqueiras. Quanto a essas últimas, podemos citar o momento em que Catarina decide colocar o seu filho mais velho, Philipp, na escola e, para isso, ela "falaria com o Dr. Hillebrand sobre o assunto, ele saberia indicar uma boa escola." (2006, p. 128).

Com os exemplos citados, fica clara a maneira com que Josué 
Guimarães serve-se da historiografia para representar Hillebrand, obtendo êxito, uma vez que consegue "trazê-lo de volta a vida" através de suas mediações com as outras personagens dentro de seu contexto histórico e, tudo isso, com o auxílio da obra A colonização alemã e o Rio Grande do Sul.

\section{Daniel Hillebrand e a colonização alemã dos Sete Povos das Missões}

Mais um tema que faz parte da representação de Hillebrand refere-se à colonização alemã na região dos Sete Povos das Missões. Segundo o narrador da ficção, Hillebrand "foi contra [a] colonização dos Sete Povos das Missões" (2006, p. 67). Porém, Hillebrand afirma para o Pastor Stilenbauer que

fora o próprio presidente o autor daquela ideia de repovoar com alemães os Sete Povos das Missões, quando os espanhóis já haviam devastado aquela província, entregando aos imigrantes uma terra arruinada, a não ser as supostas vinte mil cabeças de gado que viviam pelas cercanias, em estado selvagem. (2006, p. 51).

Ele complementa, ainda, que "o governo mandara para lá apenas a escória mandada da Europa pelo Major Schaeffer. [...] Bêbados, vagabundos, criminosos comuns, desajustados.” (2006, p. 51).

Sobre esse assunto, Roche (1969a, p. 98) explica que "o Presidente da Província submetera ao Governo Imperial um projeto pessoal", e que "apesar do silencio do secretariado do Estado, toma a si a responsabilidade de enviar, a São João das Missões, [...] certo número de imigrantes", reunindo dessa maneira "os que eram considerados indesejáveis" para essa empreitada. Roche explica ainda que, chegando lá, "os imigrantes vendem suas rações para beber, afundam na miséria e começam a sumir-se. Diante do insucesso de seu projeto, Pinheiro manda conduzir os últimos a São Borja."

No entanto, cabe levar em conta que, segundo Roche (1969a, p. 98), Hillebrand, na posição de diretor da colônia, foi quem "junta os indesejáveis no comboio que o presidente manda para a longínqua colônia de São João das Missões.”. Ou seja, nesse caso há duas formas de interpretarmos o que Josué Guimarães figurou em A ferro e fogo: a primeira delas é que na obra a personagem está tentando eximir-se de culpa, dando a entender que os efeitos desse desastre não estão relacionados a ele, ou, na segunda hipótese, o romancista tenta com essa versão ressignificar a imagem de João Daniel Hillebrand para algo mais positivo, o que acreditamos ser menos provável. De qualquer forma, se seguirmos essa mesma explicação de Roche, veremos que Hillebrand "por muito tempo, usou, como último recurso, do envio para a colônia de Torres como uma sanção" (1969a, p. 96). Esse episódio também 
está representado em A ferro e fogo. Quando perguntado da situação de São Leopoldo, Mayer diz que "o inspetor das colônias, esse inovara: valentões e bêbados mandados para os lados de Torres" (2006, p. 28). Aqui podemos perceber que se no romance não há a comprovação de participação de Hillebrand no envio de contingente a São João das Missões, há para a Colônia de Torres.

Assim, temos mais uma vez a obra historiográfica de Jean Roche como organizadora dos eventos da narrativa romanesca. Podemos notar também, por meio das ações de Hillebrand relacionadas a colonização do Sete Povos das Missões, uma possível reinterpretação e ressignificação da personagem por parte de Josué Guimarães.

\section{Personagens fictícias como possibilidades da época}

A família Schneider, à qual estão vinculadas algumas das personagens protagonistas do romance, provém da cidade alemã de Salzwedel, na Saxônia. Como ocorre com boa parte da população daquele país, os Schneider também sofrem com o colapso das fronteiras agrícolas, com o esgotamento dos antigos meios de produção frente à industrialização e com a falta de emprego devido à excessiva oferta de mão de obra que as empresas não conseguiam absorver. Atraídos pelas promessas de Schaeffer de uma vida melhor, resolvem embarcar para sua jornada na "nobre e generosa Hamburgo" (2006, p. 6), de onde o Wilhelmine levantou ferro "rumo ao desconhecido, mares bravios, terras estranhas, feras e bugres”. (2006, p.18).

A representação da origem da família confere com os apontamentos de Roche, segundo o qual "os primeiros que se fixaram no Rio Grande do Sul, provinham de Holstein, de Hanover, de Mecklembourg. Seguiram-nos, logo depois, camponeses originários de Hunsruck, estes últimos, em maior número assimilaram os que vinham de Saxe, de Württemberg ou de outras regiões." (1969a, p. 158).

A constituição familiar na ficção também segue nos moldes da pesquisa de Roche, na medida em que o historiador explana que

a população de origem germânica teve uma taxa de natalidade elevada. Parece que sua instalação no Brasil lhe favorecera o aumento do índice demográfico, sob a dupla influência da técnica agrícola, que exigia mão-de-obra abundante para o desbravamento das florestas, e da fertilidade das terras virgens, capaz de alimentar uma população numerosa, pelo menos durante certo espaço de tempo. (1969a, p. 162). 
A família Schneider era composta por Daniel Abrahão, sua esposa Catarina e cinco filhos, Philipp, Mateus, João Jorge, Carlota e Jacob. O primeiro deles emigra com os pais da Alemanha e os outros nascem na nova pátria.

É importante destacar que a família Schneider desempenha na ficção as três principais atividades econômicas mais comuns entre os imigrantes recémchegados, que são a produção agrícola na pequena propriedade, o artesanato e o comércio.

Daniel Abrahão Lauer Schneider, na Alemanha, exercia a função de artesão, mais especificamente um celeiro. Sem condições de continuar a sua vida, decide emigrar para o Brasil. Essa personagem representa o

\begin{abstract}
substrato social excedente da população alemã que, expulso dos campos pela reforma agrária e não absorvido pela indústria da Alemanha, no início do século XIX, engrossa os aglomerados urbanos miseráveis, cuja a alternativa é emigrar em busca da sobrevivência no novo mundo. [...] representa o coletivo de uma população expulsa de sua terra para atender aos interesses do capitalismo e estabelecer o equilíbrio social da Alemanha. (SANTOS, 2009, p. 47).
\end{abstract}

Porém, quando Daniel Abrahão chega à Província, esperava tornar-se agricultor, já que "o que lhes fora prometido na Alemanha [incluía] uma colônia de terras de papel passado, alguma ferramenta, sementes e animais domésticos" (2006, p. 7). Como não recebe o prometido, trata "de tirar da terra provisória algo que pudesse ser somado ao charque e às aguadas abóboras da Estância Velha" (2006, p. 7). Ainda "jurava a si mesmo que um dia, um dia não muito distante, ainda plantaria sementes de trigo na sua terra, terra de papel passado, e das sementes tiraria a farinha" (2006, p. 7). Daniel Abrahão chega a cultivar a terra durante o período em que vive na fronteira Sul, local onde "colhia mandioca, batata e cebola" (2006, p. 7).

Essa personagem torna-se, na trama do romance, representante de um grupo maior, através do qual Josué Guimarães "inverte a imagem como o imigrante alemão aparece na ficção sulina e na crônica historiográfica" (BARBIERI, 1997, p. 32-33). Na figura de Daniel Abrahão o romancista apresenta "um imigrante agricultor e homem da terra que procura adaptar-se ao novo mundo, questionando e/ou aceitando novos valores, adotando lutas que considera justas." (BARBIERI, 1997, p. 33).

Daniel Abrahão também aparece carregado de significados históricos, muitos deles podendo ser captados por meio de suas memórias, algumas relacionadas aos seus familiares e as suas devidas participações em eventos e episódios cruciais, momentos de ruptura ocorridos na Europa pré-migração. 
Um exemplo disso ocorre quando Daniel Abrahão, por meio de seus devaneios em sua toca, sonha com a Batalha de Waterloo4 e vê a figura do "velho corneteiro Schneider, seu pai, assoprando desesperado, as veias do pescoço saltadas, e depois caindo varado de balas. As tropas em debandada, os quadrados flanqueados e desfeitos, os campos juncados de mortos e feridos, armas abandonadas" (2006, p. 63), ou também na lembrança de sua viagem à Província, a bordo do navio São Francisco de Paulo. Ele recorda o que presenciara nos porões do navio: "semanas e semanas intermináveis, a promiscuidade pondo a vergonha de lado, os casais aproveitando o barulho das vagas quebrando contra o frágil casco de madeira a ranger, a excitação se alastrando de casal a casal até confundir-se com o bramir do mar." (2006, p. 16-17).

Assim, alguns episódios da saga dos Schneider são narrados a partir da memória das personagens, em que o presente recupera o passado para dar sentido ao novo contexto regional. A técnica memorialística, nesse sentido, constitui na trama um importante fator de resgate, já que busca trazer à tona episódios passados a fim de integrá-los ao presente, de modo que se possa desse modo fazer uma desleitura da história oficial e da literatura ufanista. Com os lances de precariedade recuperados pela memória, a história da imigração, focalizada na família Schneider, ganha contornos mais de penúria do que de glória.

Barbieri, no seu ensaio Colonização a ferro e fogo, corrobora um entendimento nesse sentido, quando afirma que através dessa memória “o passado vem a tona das águas presentes, misturando-se com percepções do imediato. A memória/lembrança aparece como força subjetiva, ao mesmo tempo profunda e ativa, latente e penetrante, oculta e invasora." (1997, p. 29).

Também podemos notar em Daniel Abrahão uma nostalgia constante de hábitos e costumes que ficaram na Alemanha, principalmente em relação a certos alimentos. Recém-chegado à nova terra, ele costuma à noite sonhar "com o cheiro de pão fresco da Europa, com o perfume das cucas açucaradas, com a fritura das grossas salsichas e do chucrute conservado na vinha-d'alhos"

4 A Batalha de Waterloo foi um confronto militar ocorrido em 18 de junho de 1815, nas proximidades de Waterloo, parte que então integrava o Reino Unido dos Países Baixos, atual Bélgica. Nesse episódio o Imperador Napoleão foi derrotado pelos exércitos da Sétima Coligação, dos quais faziam parte uma força britânica sob o comando do Duque de Wellington, e uma força prussiana liderada pelo marechal-decampo Gebhard Leberecht von Blücher. Esse episódio decretou o último ato de Napoleão, pois sua derrota rendeu o fim de seu posto de imperador, e consequentemente, o fim de seu governo. 
(2006, p. 9). Sua esposa compartilha do mesmo sentimento, já que tem "pensado no [...] pão da Alemanha, nas cucas estufadas extravasando das formas." (2006, p. 9).

Os momentos de nostalgia de Daniel Abrahão também surgem quando ele ouve as antigas histórias de sua terra com seus amigos e, juntos, "cantavam as velhas e marciais canções da Alemanha, chupando das canecas o resto de cerveja, Schneider sentia na boca o gosto ardido das lágrimas." (2006, p. 9). De certa forma, são essas lembranças e o desejo de viver as mesmas experiências deixadas para trás que motivam as ações da personagem em relação à produção para o consumo da família. $\mathrm{Na}$ fronteira, quando fazem pão pela primeira vez, a empolgação era tanta que "Daniel Abrahão cantarolava uma velha canção da Altmark, arrastando a mulher, sob protestos dela, numa dança grotesca que arrancou gargalhadas dos escravos" (2006, p. 26), afirmando que aquele era "o autêntico pão da Alemanha." (2006, p. 26). O pão como alimento básico não parece ser tão importante por acaso no romance. Conforme afirma Roche, "num prazo inferior a dez anos, todas as colônias foram dotadas de moinhos de cereais, para permitir que os colonos voltassem a comer pão" (1969b, p. 481), visto que não estavam dispostos a regredir socialmente, pelo menos no que diz respeito à alimentação com a qual estavam acostumados em sua terra natal.

Essa nostalgia, embora esteja relacionada ao isolamento ou escassez de recursos, também acentua a dificuldade de adaptação da personagem à região, uma vez que Daniel Abrahão possui uma forte inclinação para o lado mais prático de seu enfrentamento diário, buscando na maior parte do tempo em seus sonhos os víveres tão desejados de sua terra natal, não tomando iniciativa em momento algum para obtê-los. Se por um lado essa personagem pode ser interpretada como "uma representação de uma tendência masculina entre os alemães: o modo de ser depressivo, cabisbaixo, fechado em si mesmo." (AQUINO, 2010, p. 247), por outro pode-se notar nele a falência dos sonhos dos imigrantes de alcançarem uma vida melhor, já que ao chegar na nova terra percebe que nada do que fora prometido se cumpriu, restando apenas a permanência da situação de miséria, porém, agora, com o agravante de estar distante de suas famílias e de suas tradições.

Podemos notar ainda, no período em que a família Schneider vive na fronteira Sul da Província, a inclinação dos imigrantes pelo destilado de cana. Um exemplo disso ocorre quando Mayer chega ao rancho dos Schneider e pede "um trago para refrescar", dizendo ainda que "não precisa economizar que trouxe dois corotes, dos grandes, da melhor aguardente de Torres" (2006, p. 26), ou quando pela primeira vez Frederico chega à Estância de Jerebatuba e 
"foram beber algo em comemoração, uma cachaça trazida pelos visitantes, em garrafas" (2006, p. 24). Nesse sentido, em relação aos hábitos alimentares, as personagens alemãs procuram preservar a culinária trazida da Alemanha, ao mesmo tempo em que se abrem para a degustação de produtos nativos. Em A colonização alemã e o Rio Grande do Sul, Roche aponta que "os colonos, muito cedo adotaram o aguardente de cana, que desempenhou um papel tanto mais importante quanto a fabricação da cerveja não conseguiu introduzir-se no decurso desse período." (1969b, p. 481).

A representação de Daniel Abrahão também denota as barreiras culturais enfrentadas pelos imigrantes. Uma delas, talvez a principal, refere-se à língua, a qual durante grande parte da obra mostra-se presente na relação entre os imigrantes, os teuto-brasileiros e os castelhanos.

Quando estava desesperado, no início da Guerra da Cisplatina, ao descobrir que fazia parte de um esquema de contrabando de armas, pensa em falar com o general da tropa e dizer que "deixaram isso aí, não sei de quem é essa coisa, podem levar, tomem conta" (2006, p. 43). No entanto, sua mulher o questiona: "em que língua vais falar com eles?" (2006, p. 43). A pergunta revela o isolamento em sua nova pátria, onde os imigrantes "se tornaram eles mesmos a fronteira" (RIBEIRO, 2009, p. 8), visto que "o emprego exclusivo do alemão prolongou-se além do fim do império, pois, em 1885, ainda se salientam os progressos da língua alemã nas colônias, onde os imigrantes podem viver sem compreender uma palavra do português" (1969b, p. 654). Cabe salientarmos ainda que, no romance, são justamente diferenças como a língua "que definem as heranças culturais e a ideia de pertencimento." (RIBEIRO, 2009, p. 8).

Josué Guimarães encara questões culturais como essa, da linguagem, de maneira natural, sem juízos de valor, sem buscar em nenhum momento elevar ou diminuir a sua importância, já que sua intenção não é idealizá-las, mas, sim, representá-las de maneira natural aos seus leitores. Sobre isso, Aquino (2011, p. 1662) destaca que Josué Guimarães "não julga a preservação da língua, da idiossincrasia e das manifestações culturais identitárias das colônias alemãs. Ele se propõe a construir um olhar, narrar e descrever, num misto de ficção e história, recriando o passado de um ponto de vista próprio."

Dessa forma, no que tange a representação da família Schneider, percebemos que Josué Guimarães se embasou na obra histórica nos mínimos detalhes, representando questões relacionadas às memórias trazidas do velho continente, constituição familiar, atuação profissional, hábitos alimentares e o próprio processo de aculturação dos imigrantes. 


\section{A construção ambiental em A ferro e fogo}

Um aspecto notório representado no romance é a evolução das casas no decorrer da narrativa, cujo material de construção passa de madeira a tijolos. Há no romance uma passagem em que Catarina contrata Herr Mühlen para construir uma nova casa. O romancista apresenta de forma detalhada o processo de edificação nas intervenções do construtor e da própria Frau Schneider. A casa representada na narrativa assemelha-se em seus detalhes às apresentadas nas plantas das páginas 200 e 201 da obra A colonização alemã e o Rio Grande do Sul. Além disso, o que mais nos chama a atenção é o fato de

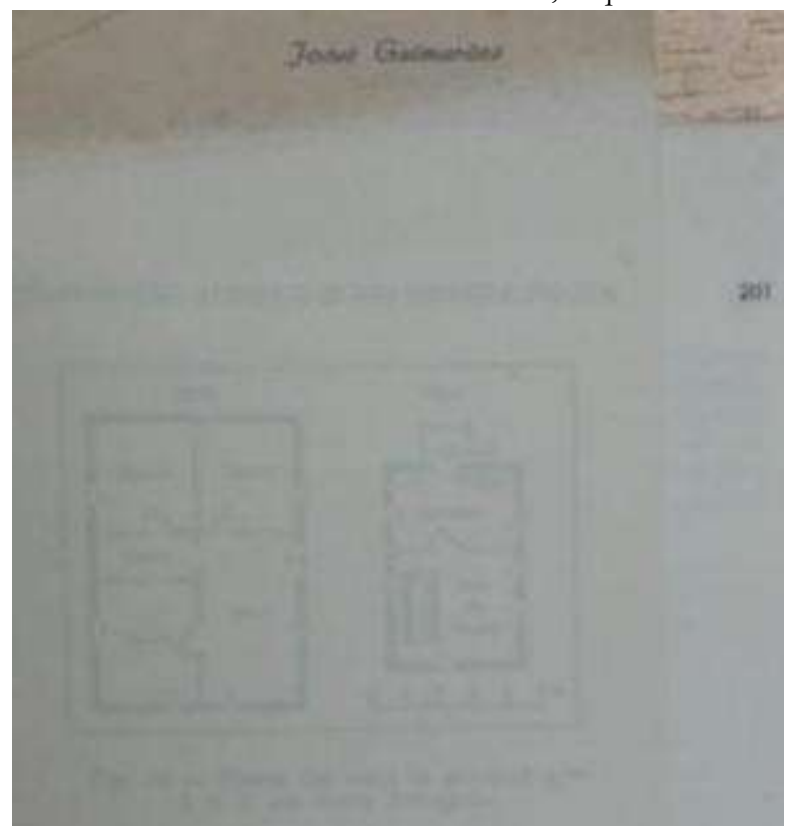
haver um papel como marcador nessas páginas da obra de Roche localizada no Acervo Josué Guimarães, conforme pode ser observado na Figura 2.

FIGURA 2 - Planta baixa de casa típica do período da imigração alemã (1824)

Fonte: ROCHE, 1969, p. 201.

numa ladeira, assentada num muro de pedra insossa que assegura a circulação do ar sob o assoalho" (1969a, p. 200). Já na representação de Josué Guimarães, Catarina ampara-se na planta da casa para explicar a Emanuel que: "aqui se assenta o alicerce, o muro levanta mais, pedra sem barro e sem argamassa, assim o vento entra e não deixa o assoalho apodrecer" (2008, p.176). Roche segue adiante explicando que "as paredes [são] de tijolos" enquanto "as divisões internas são de tábuas caiadas de branco" (1969a, p. 200). Já na explicação sobre a sua casa, Catarina argumenta que "as paredes todas vão ser de tijolos", e apenas "as divisões, com tábuas caiadas." (2008, p. 176). Dessa forma, nota-se a busca detalhada de Josué Guimarães em tentar apresentar o 
ambiente da colônia da forma mais verossímil possível, para assim garantir à narrativa fidelidade em relação a tempo e espaço.

Interessante atentarmos para esse detalhe das imagens contidas na obra histórica e compará-las com as discrições feitas no romance, pois podemos notar que o autor de A ferro e fogo busca de maneira meticulosa a verossimilhança nas representações das residências em sua obra, desde as telhas, passando pelos detalhes das paredes, portas e janelas, chegando à pintura caiada. A provável explicação para que isso ocorra no romance está na intenção do autor de fidelizar ao máximo sua obra, no intuito de apresentar de forma similar o panorama ambiental da época.

\title{
Considerações finais
}

Há no início da obra A colonização alemã e o Rio Grande do Sul, de Jean Roche, o prefácio escrito por R. Poirier, o qual faz uma espécie de sugestão, ou até mesmo uma provocação, onde diz que

\begin{abstract}
Não se pode pedir-lhe que escreva o romance da tese, e, no entanto, desejar-seia que um romancista nos apresentasse, antes que se perca inteiramente a própria lembrança dela, a vida dessas comunidades rurais, a administração patriarcal dos diretores, a vida religiosa durante o longo período em que protestantes e católicos conservaram sua fé, sem pastores e sem padres, as preocupações do amor e da vida familiar, a educação dos filhos, o tédio talvez, a asfixia econômica, a emigração para as colônias novas, ao preço de que esforços e de que renúncias!
\end{abstract}

Sendo assim, por meio das análises anteriormente feitas, não nos resta dúvida de que Josué Guimarães tomou para si tal missão, e conseguiu, por intermédio da obra de Roche, transformar uma compilação de datas, dados e acontecimentos em um mundo vivo, colorido, onde figuram personagens construídas segundo os padrões da época abordada e lideranças históricas que agem de acordo com as possibilidades do período em que viveram, ao mesmo tempo em que são representados em segundo plano os eventos históricos que impactam diretamente em suas vivências e nos seus modos de agir. 


\section{Referências}

CERTEAU, Michel de. A escrita da história. 3. ed. Rio de Janeiro: Forense, 2015.

CHARTIER, Roger. A mão do autor e a mente do editor. São Paulo: Editora Unesp, 2014.

FERREIRA, Pricilla de Oliveira. O romance histórico na literatura portuguesa contemporânea. Revista eletrônica de crítica e teoria de literaturas, Porto Alegre, v. 5, n. 2, p.1-18, jul./dez. 2009.

GUIMARÃES, Josué. A ferro e fogo: tempo de solidão. $15^{a}$ ed. Porto Alegre: L\&PM Editores, 2006.

GUIMARÃES, Josué. A ferro e fogo: tempo de guerra. $10^{\mathrm{a}}$ ed. Porto Alegre: L\&PM Editores, 2008.

LUKÁCS, György. O romance histórico. São Paulo: Boitempo, 2011.

PESAVENTO, Sandra Jatahy. O mundo como texto: leituras da história e da literatura. In: Revista História da Educação, n. 14, p. 31-45, set. 2003.

RICOEUR. Paul. Tempo e narrativa: a intriga e a narrativa histórica. São Paulo: Editora WMF Martins Fontes, 2010a.

RICOEUR. Paul. Tempo e narrativa: a configuração do tempo na narrativa de ficção. São Paulo: Editora WMF Martins Fontes, 2010b.

RICOEUR. Paul. Tempo e narrativa: o tempo narrado. São Paulo: Editora WMF Martins Fontes, 2010c.

ROCHE, Jean. A colonização alemã e o Rio Grande do Sul. Porto Alegre: Editora Globo, 1969a. v. I.

ROCHE, Jean. A colonização alemã e o Rio Grande do Sul. Porto Alegre: Editora Globo, 1969 b. v. II.

ROMANI, Carlo. A teoria da História, o romance histórico e a crise do realismo burguês. Disponível em: <http://docslide.com.br/education/ateoria-da-historia-e-o-romance-historico-em-lukacs.html> Acesso em: 04 nov. 2015.

SANTOS, Elaine dos; LIPKE, Rose Rehbein. Literatura e história: representações da imigração alemã através de A ferro e fogo I - tempo de solidão. Revista do Centro de Artes, Humanidades e Letras, Cachoeira, vol. 3, p. 38-54, 2009. 
SANTOS, Pedro Brum dos. Literatura e intervenção: romance histórico no Brasil. Floema, Vitória da Conquista, ano VII, n. 9, p. 283-303, jan./jun. 2011.

ZILBERMAN, Regina. Saga familiar e história política. In: GONÇALVES, Robson Pereira (Org.). O tempo e o vento: 50 anos. Santa Maria; Bauru: Ufsm/Edusc, 2000. p. 25-42.

\footnotetext{
Abstract: The present work has as objective investigate the relationship between history and literature from the historical novels A ferro e fogo: tempo de solidão and A ferro e fogo: tempo de guerra, by Josué Guimarães, together with the two volumes of the work A colonização alemã e o Rio Grande do Sul, by french historian Jean Roche, analyzing the way in which the historian's narrative serves as a source of research for the novelist and the process of fictionalization of history.
}

Keywords: A ferro e fogo; Josué Guimarães; Jean Roche; history; literature 